\section{ECONOMICS}

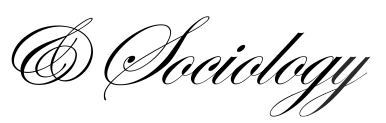

Kostynets, I., Kostynets, V., \& Baranov V. (2020). Pent-up demand effect at the tourist market. Economics and Sociology, 13(2), 279-288. doi: 10.14254/2071789X.2020/13-2/18

\title{
PENT-UP DEMAND EFFECT AT THE TOURIST MARKET
}

\author{
Iuliia Kostynets \\ National Academy of \\ Management, \\ Kyiv, Ukraine \\ E-mail:yulia.kostinets@gmail.com \\ ORCID 0000-0001-6427-675X
}

Valeriia Kostynets

Kyiv National University of

Technology and Design,

Kyiv, Ukraine

E-mail:vvaleriya1989@i.ua

ORCID 0000-0002-4222-7620

\author{
Vitalii Baranov \\ National Aviation University \\ Flight Academy, \\ Kropyvnytskyy, Ukraine \\ E-mail:vaiss@ukr.net
}

Received: November, 2019

1st Revision: February, 2020

Accepted: June, 2020

DOI: $10.14254 / 2071-$

789X.2020/13-2/18

JEL Classification: R22, L83, G01, O50
ABSTRACT. The article is dedicated to modeling of the effect of the pent-up demand situation at the tourist market caused by the current epidemiological situation in the world. The authors have investigated the current trends at the global travel services market in connection with the COVID-19 outbreak. The article determines that tourism is most sensitive to the crises of epidemiological, political and economic nature. In this regard, the authors analyzed the situation with pent-up demand for tourist services based on the data from the previous periods. To simulate the effect of the pent-up demand situation at the tourist services market, the authors are looking at tourism products in Italy and France, considering the current COVID-19 outbreak in these countries. The authors analyzed the English-language and Russian-language queries "Tours to Italy" and "Journey to Paris" using the Google Trends data and determined the dynamics of search queries over the past five years. The correlation analysis has confirmed that the popularity of searches from potential consumers is closely correlated with the volume of real demand for tourist services.

\section{Introduction}

Current epidemiological situation in the world, which will certainly result in the deepening of the global financial crisis, has affected all sectors of the economy. Negative effects have been already felt by service companies and, in particular, by tourism businesses. In fact, travel companies find themselves in a situation of lack of both supply and demand, given the introduction of strict quarantine measures around the world, restrictions on international transport and on the operating regimes of hotels and restaurant businesses. The World Travel and Tourism Council predicts the loss of up to 50 million jobs in the tourism and hospitality sector due to the current pandemic, with the travel sector directly reduced by $25 \%$ (UNWTO, 
2020). Accordingly, today, business owners are facing the urgent issue of forming and stimulating pent-up demand in the face of an epidemiological situation and economic crisis.

The current situation at the world market of tourist services is significantly different from any other previously studied periods. At the same time, consumer decisions do not always fit into the existing consumer behavior patterns, even in a difficult epidemiological situation, underpinned by the global financial stagnation. For example, the most striking feature in the behavior of Ukrainian consumers of tourist services in the face of such crises is not to make savings, but rather maximum realization of the available free money. In this regard, formation of pent-up demand requires additional research.

Structurally, this study consists of the following sections: 1) introduction with indication of the relevance of the issue under study; 2) review of the literature on the issues of pent-up demand formation; 3) definition of the purpose, objectives and methodology of the research; 4) coverage of the main theoretical results of the study and demonstration of the empirical implementation of the research results; 5) conclusions and prospects for further research.

\section{Literature review}

The problem of demand generation has been researched by scientists and practitioners for a long time. According to the studies of A. Zadoya (2014), N. Alekseev and S. Ilchenko (2013) demand is one of the most important factors of economic growth. In addition, demand is an indicator of the standard of living, as it is a real expression of purchasing power in the consumer market. At present, there is no special debate about the essence of the concept of demand. Demand as an economic category is heterogeneous in space and time. Most of the scientific work is related to the study of demand, focused either on the study of demand dynamics, its structure and volume (as shown in the works of Y. Gaoa, S. Rasoulib, H.Timmermansb (2014), I. Antokhonova (2005)) or regional features of consumption (as evidenced by the results of studies by A. Novosyolov (2002), N. Feoktistova (2009), D. Streimikiene et al.(2015)) or channel of distribution (as presented by V. Roudposhti et al. (2018) and S. Vaitkevičius et al. (2019).

The nature of pent-up demand has also received considerable attention in both domestic and foreign studies. Thus, N. Oleynyk defines it as the demand for expensive goods, the money for which are pent-up by buyers (Oleynyk, 2013). According to A. Solomatina pent-up demand is an existing, but for various reasons, for example, when it is necessary to accumulate a certain amount of money for the purchase of a specific good and service, the obligatory purchase of a good or service for a particular event, etc. (2000).

For the purposes of studying pent-up demand, works that take into account the issues of equalization of consumption are of particular interest. These are the theory of permanent income by M. Friedman (1948), the life cycle theory by A. Ando and F. Modigliani, as well as the model by Casa-Kupmans-Ramsay (2010), in which the norm of substitution is an endogenous variable through two additional parameters: intertemporal elasticity of substitution and the norm of time preference. The latter model substantiates that, based on its temporal preference, the individual refuses the true preference for the benefit of the future ones if interest rates are high enough. Psychological factors of saving behavior have been studied in the works of $G$. Katona (1951), A. Tversky and D. Kahneman (1974).

Crisis manifestations and associated uncertainty are the strongest factors in pent-up demand. Often, in times of instability, the population increases savings by postponing previously scheduled purchases. Since pent-up demand is a need, whose satisfaction is shifted towards the future, it is obvious that it is formed only on condition that in the future, if income does not increase, then it will remain at the pre-crisis level, and a person will be able to return 
to its "consumption curve". Otherwise, in the case of decreasing income for a long time, the person usually does not postpone the purchase, but changes its curve of pent-up demand. Therefore, the research of demand of the last quarter of 20th century is connected precisely with the factor of uncertainty. It should be noted that the real savings behavior of households begins to deviate significantly from the predictions of neoclassical models. The processes of formation of pent-up demand are based on buffer-stock models (Caroll, 1997; Deaton, 1991), as well as the ideas of R. Wahlund and I. Gunnarsson, who have shown the dependence of people's savings behavior on their previous financial experience (1996).

Based on the literature review, it should be noted that despite the presence of sufficient scientific developments related to the issue of pent-up demand, the topic of pent-up demand for tourist services with regard to the functioning of the market in the context of epidemiological threats and related political \& economic crises remains unanswered as of now.

\section{Methodological approach}

The purpose of the study is to simulate the effect of a pent-up demand situation on the tourist services market, based on the current epidemiological situation in the world.

According to the purpose, the main objectives of the study were to determine the current state and prospects of a decline in the tourist services market in connection with the outbreak of the coronavirus epidemic in the world; defining the features of pent-up demand and to determine the trend of pent-up demand based on the results of the stabilization of the epidemiological situation.

Methods of structural and functional analysis, scientific abstraction, as well as graphical method and method of trend equations and adaptive forecasting were used for detailed research.

In the context of rapid wave-like changes in the conditions of the external macroenvironment over time, the presence of incomplete data and constant updating of variables, it is advisable to use such type of statistical analysis and time series forecasting, which is able to adapt to the constant changes of socio-economic processes - adaptive modeling, founded by $\mathrm{G}$. Brown (2004), A. Tale, S. Wage (1964), P. Winters (1960), S. Halt (1957).

\section{Conducting research and results}

The tourism and hospitality industry around the world is very negative about the pandemic because of the nature of business that is always associated with people's travel. History has shown that epidemics and pandemics have an immediate impact on the activities of the hotel and restaurant business, airlines, tour operators and agents, etc. through international travel restrictions, sufficiently panic coverage of the epidemiological situation in the media, and the harsh actions of governments in different countries. As of now, the tourism industry is one of the most affected by the COVID-19 coronavirus epidemic, which affects both demand and supply, poses additional risks to the industry in a conditions of weakened global economy, geopolitical, social and trade tensions, as well as uneven opportunities among major travel outbound markets.

\subsection{Impact of the COVID-19 Coronavirus Outbreak on Tourism}

Given the current situation, it is not possible to assess the final impact of the COVID19 coronavirus epidemic on international tourism. For its initial assessment, tourism experts, and in particular the World Tourism Organization (UNWTO), are targeting the SARS 2003 pandemic as a benchmark, considering the magnitude and dynamics of global travel and current 
disruptions, the geographical spread of the new virus and its potential impact. Thus, according to UNWTO estimates, global tourist income in 2020 may decrease by $1 \%$ to $3 \%$, which is less than the forecasted increase of 3-4\% in early January 2020 Such dynamics can lead to a loss of USD 30-50 billion in international tourism revenue. Currently, Asian and Pacific regions are expected to suffer the most (with international tourist income decreasing by $9 \%$ to $12 \%$, down from 5-6\% in early January 2020 (UNWTO, 2020). Estimates in other regions of the world are not provided at this time, given the dynamics and variability of the epidemiological situation. In particular, the COVID-19 outbreak caused a major crisis in Italian tourism - a 40\% reduction in its sector. Hundreds of bookings have been canceled and future bookings have dropped significantly by the end of June. Impact on tourism in Spain, Greece, France, the United Kingdom and other countries will also be significant.

Overall, the tourism industry in Europe suffered losses of about USD 2 billion in January-February 2020 Due to the coronavirus outbreak, 250 Chinese tourists did not arrive in Europe in January-February this year, a loss of about 2 million days in hotel accommodation.

The level of panic among tourists in connection with COVID-2019 plays an important role in the estimation of potential losses for tourism and is now quite high. The World Travel and Tourism Council estimates the loss of 22 billion euros in worldwide tourism revenue due to the outbreak of a coronavirus pandemic (Guevara, 2020). The calculations are based on the experience of previous crises, such as SARS or H1N1. Among European countries, the biggest losses in the tourism industry will be in Italy, which has now become the epicenter of the coronavirus outbreak in Europe. According to experts, in 7-8 months the losses could reach 50 million euros (Guevara, 2020). As of March, nearly $90 \%$ of bookings have already been canceled, and overall bookings have decreased for every month until June.

International carriers are also no exception to this disaster. A sharp fall in demand will affect all airlines, buses and rail carriers. IATA estimates that the coronavirus will cause a decrease in world passenger traffic by 4,7\% and a loss of passengers of 29,3 billion dollars (Tounta, 2020). The great negative economic impact will also have cancellation of several international exhibitions and expos around the world. Among the latest canceled events - the largest exhibition of mobile technologies - Mobile World Congress in Spain, which had to be held in late February and receive more than 100 thousand visitors, Geneva Motor Show in Switzerland, which was expected to receive more than 600 thousand visitors, and the most influential tourist exhibition in the world - ITB-Berlin in Germany, which was expecting to receive 10 thousand participants from 180 countries.

Considering the above, we can say that tourism is the most sensitive area to various economic and epidemiological crises. As of now, in the tourism industry, we can observe the state of unconditional "stagnation", which, at the same time, should be considered as a pent-up demand effect.

\subsection{Pent-up demand for tourist services}

Demand formation in certain tourist destinations is related, first of all, to the image of the tourist area. At the same time, in the post-epidemiological period, the world market for tourist services will reopen: completely new tourist regions may well compete with established tourist zones in terms of originality of supply, additional service and quality of accommodation facilities. There is, however, a problem of restructuring demand in the outbound tourism market, when the maximum cash flow exported from the country has formed in such destinations as: Turkey, Egypt, Greece - these destinations in particular has shaped tourists' demand for leisure and hotel services. In case of refusal for one reason or another from the previous opportunity to visit these countries or not having it due to the peculiarities of the 
epidemiological situation in one or another country, tourists will look for an analog of service in other countries, but usually in the usual price range, there is no alternative. Then the pent-up demand is formed, and these tourists, after waiting for the stabilization of the epidemiological situation, will in any case try to visit the usual destinations.

Particular attention to the pent-up demand for tourism services should be given to tours to Europe, as it is such European countries as Italy and France that are currently at the center of the epidemic outbreak. In fact, one of the most popular Google queries before the outbreak of the COVID-19 coronavirus was "Tours to Italy".

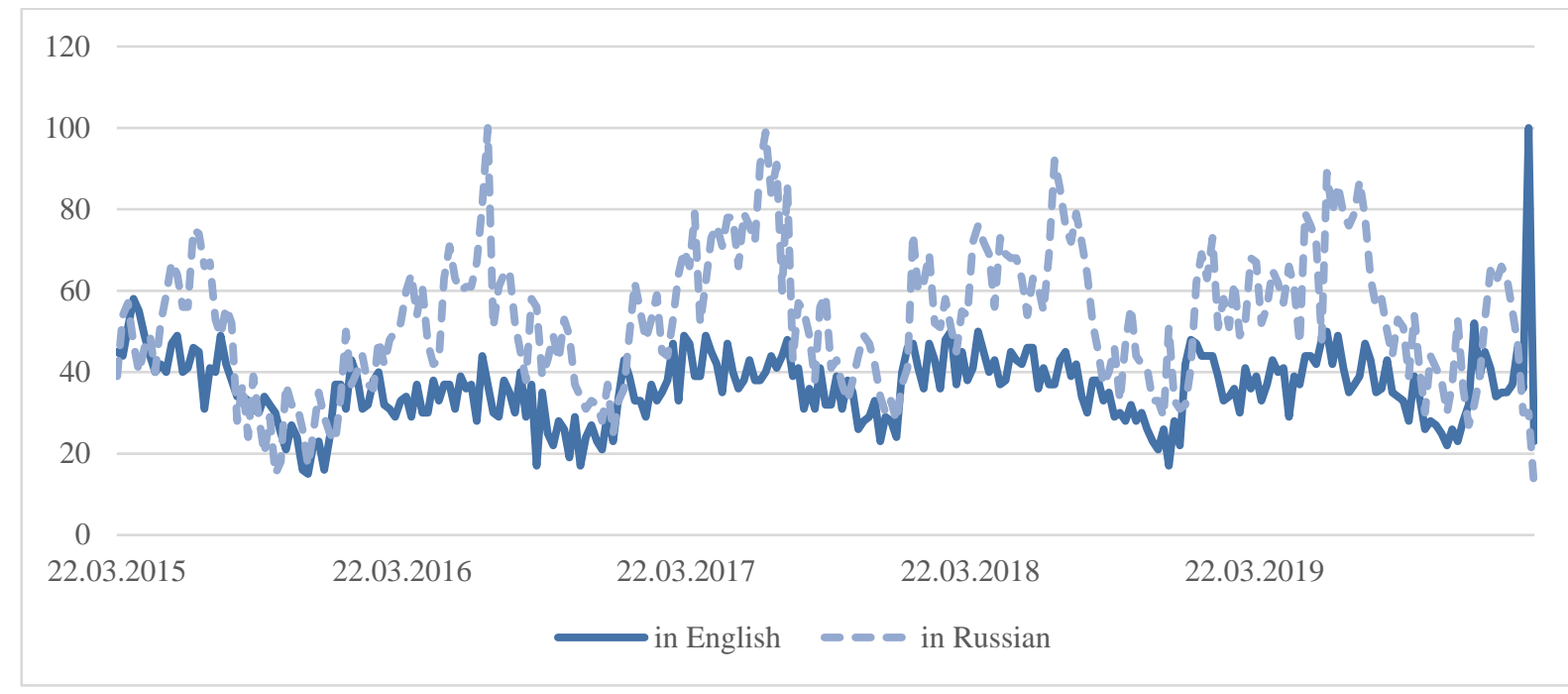

Graph 1. Trends of English-language and Russian-language requests for "Tours to Italy" according to Google Trends

Source: own data

The results shown in this figure show a clear seasonality in the inquiries of potential consumers of the tourist product "Tours to Italy" during March 2015 - January 2020 Thus, the greatest increase of both English-language and Russian-language inquiries "Tours to Italy" is observed annually in the summer season, while the fluctuations in the dynamics of Englishlanguage inquiries are more uniform, which is due, first of all, to the lack of habit of Englishspeaking consumers in traveling exclusively in the summer season. The situation with the rapid decline in the number of Russian-language queries in January 2020 and, at the same time, the sharp rise in English-language queries, when there was no significant COVID-19 coronavirus outbreak and nationwide quarantine, were quite interesting.

The "Trip to Paris" query was also very popular among potential consumers. The French capital also remains one of the most popular destinations in the world for travelers from all continents.

From Graph 2 we observe that queries for a trip to Paris over the five-year period have reached their minimum in March 2020 In general, a retrospective analysis of search queries shows that in November 2015, immediately after the terrorist attacks on November 13 and 14, 2015, English and Russian-language queries for travel to Paris reached a minimum in 20152019 period, but in January 2016 number of queries have almost reached the peak in the analyzed period. Also, a decline in "Trips to Paris" queries has been observed following the protests of the Yellow Vests in November 2018 Thus, it can be concluded that the potential demand for tours to the French capital is not so much seasonal, but depends on external factors, 
usually political. The study also shows that minimum number of "Trips to Paris" queries was reached in March 2020 prompted by a worldwide quarantine.

Observations on the dynamics of search queries indicate that potential consumers of tourist services respond promptly to changing environmental conditions by changing their queries on the network.

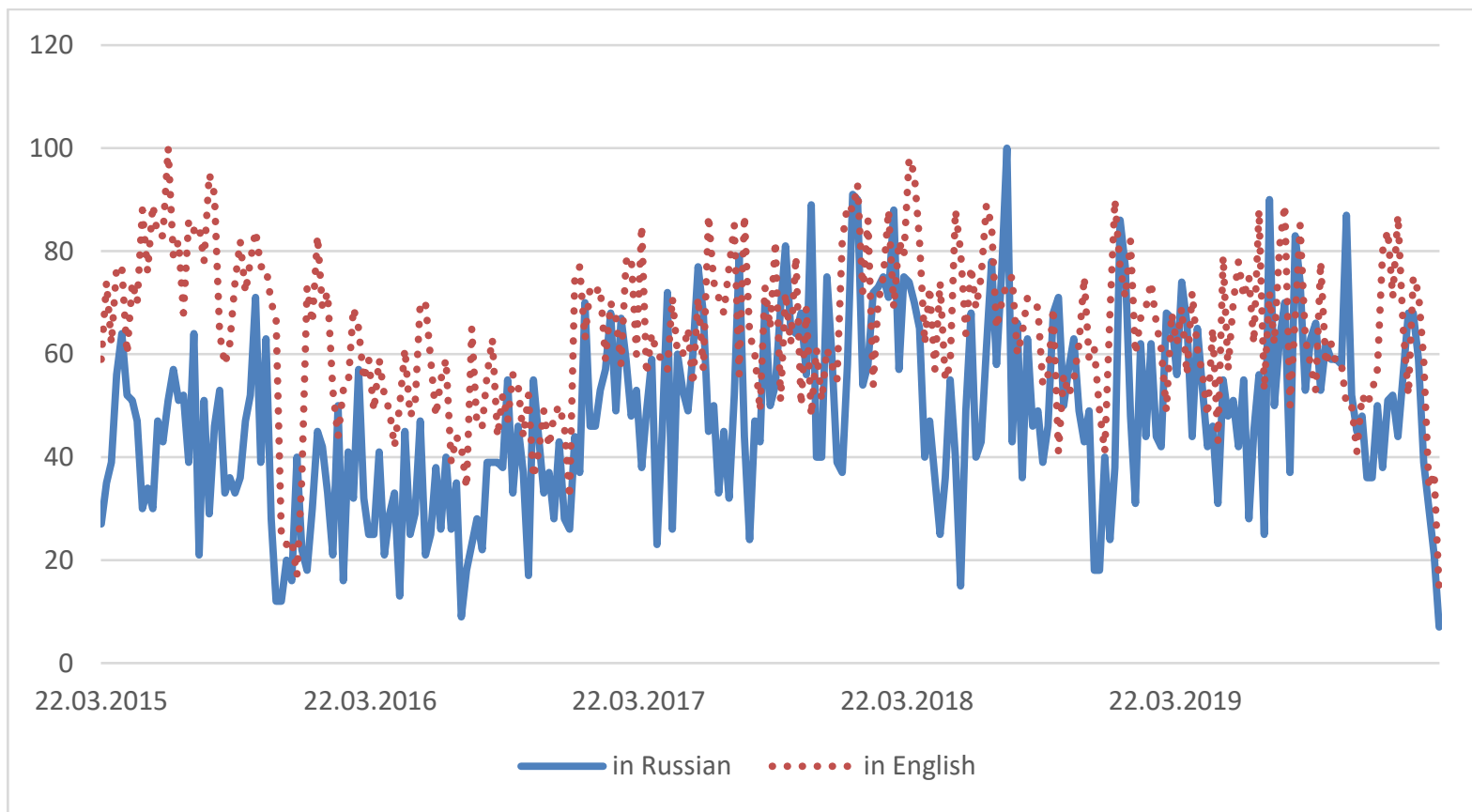

Graph 2. Trends of English and Russian-language queries for "Trips to Paris" according to Google Trends

Source: own data

Accordingly, the claim that pent-up demand simulation is based on the hypothesis that the popularity of search queries by potential consumers is closely correlated with the volume of real demand for tourism services.

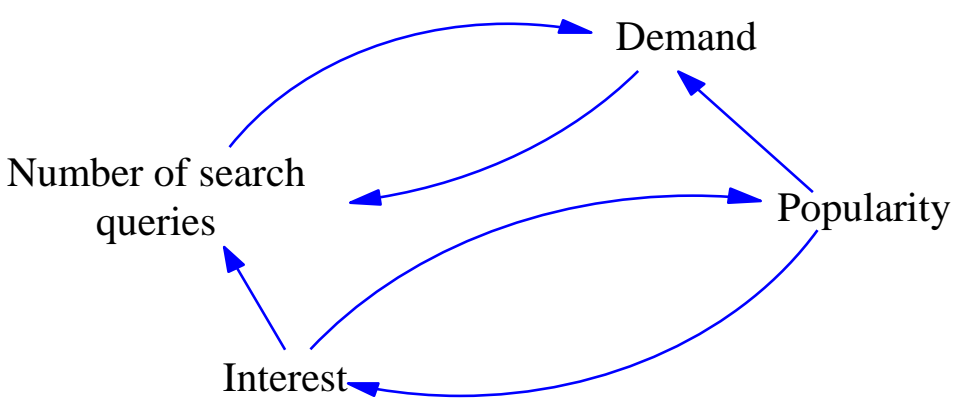

Graph 3. Correlation between search frequency, popularity and search objects Source: own data 

feedback.

Thus, correlation between search frequency, popularity and demand is cyclic with

The corresponding correlation analysis confirms this hypothesis, in particular, the correlation matrix (Table 1) indicates that there is a close relationship between the search popularity indicators in English-language and Russian-language and the tourist arrivals to the country and the money received by the country from inbound tourism.

At the intersection of columns and rows there is a correlation coefficient that has values within $[-1 ; 1]$. If the correlation coefficient is within $[-0,2 ; 0) \mathrm{U}(0 ; 0,2]$ - very weak correlation; within $[-0,5 ;-0,2) \mathrm{U}(0,2 ; 0,5]$ - weak correlation; within $[-0,7 ;-0,5)) \mathrm{U}(0,5 ; 0,7]$ - moderate correlation; within $[-0,9 ;-0,7) \mathrm{U}(0,7 ; 0,9]$ - strong correlation; within $[-1 ;-0,9) \mathrm{U}(0,9 ; 1] 1] \mathrm{i}$ very strong correlation.

Table 1. Correlation between search frequency for "Tours to Italy", number of arrivals to Italy and receipts from international tourism

\begin{tabular}{lcccc}
\hline & $\begin{array}{c}\text { Search frequency } \\
\text { in English }\end{array}$ & $\begin{array}{c}\text { Search frequency } \\
\text { in Russian }\end{array}$ & $\begin{array}{c}\text { International tourism, } \\
\text { number of arrivals }\end{array}$ & $\begin{array}{c}\text { International tourism, } \\
\text { receipts }\end{array}$ \\
\hline $\begin{array}{l}\text { Search frequency } \\
\text { in English }\end{array}$ & 1 & & & \\
\hline $\begin{array}{l}\text { Search frequency } \\
\text { in Russian }\end{array}$ & 0,902437 & 1 & & \\
\hline $\begin{array}{l}\text { International tourism, } \\
\text { number of arrivals }\end{array}$ & $-0,99256$ & $-0,90839$ & 1 & \\
\hline $\begin{array}{l}\text { International tourism, } \\
\text { receipts }\end{array}$ & $-0,97039$ & $-0,96338$ & 0,98453 & 1 \\
\hline
\end{tabular}

Source: own data

Based on the smoothing of the time series, one can predict the dynamics of search queries for tourist services, reflecting trends in demand for tourist services, which is pent-up in conditions of the worldwide quarantine.

We believe that it is possible to estimate the future effect of pent-up demand by using a multifactor adaptive regression model, as adaptive regression models are able to quickly adapt their structure and parameters to changing conditions. In the short-term forecasting, as well as forecasting in the situation of changes in external conditions, when the most recent manifestations of the studied process are the most important, adaptive models are the most effective. Graph 4 shows the forecast dynamics of the popularity of search queries based on the smoothing between Russian-language and English-language queries for travel services such as "Tours to Italy" and "Trips to Paris". 


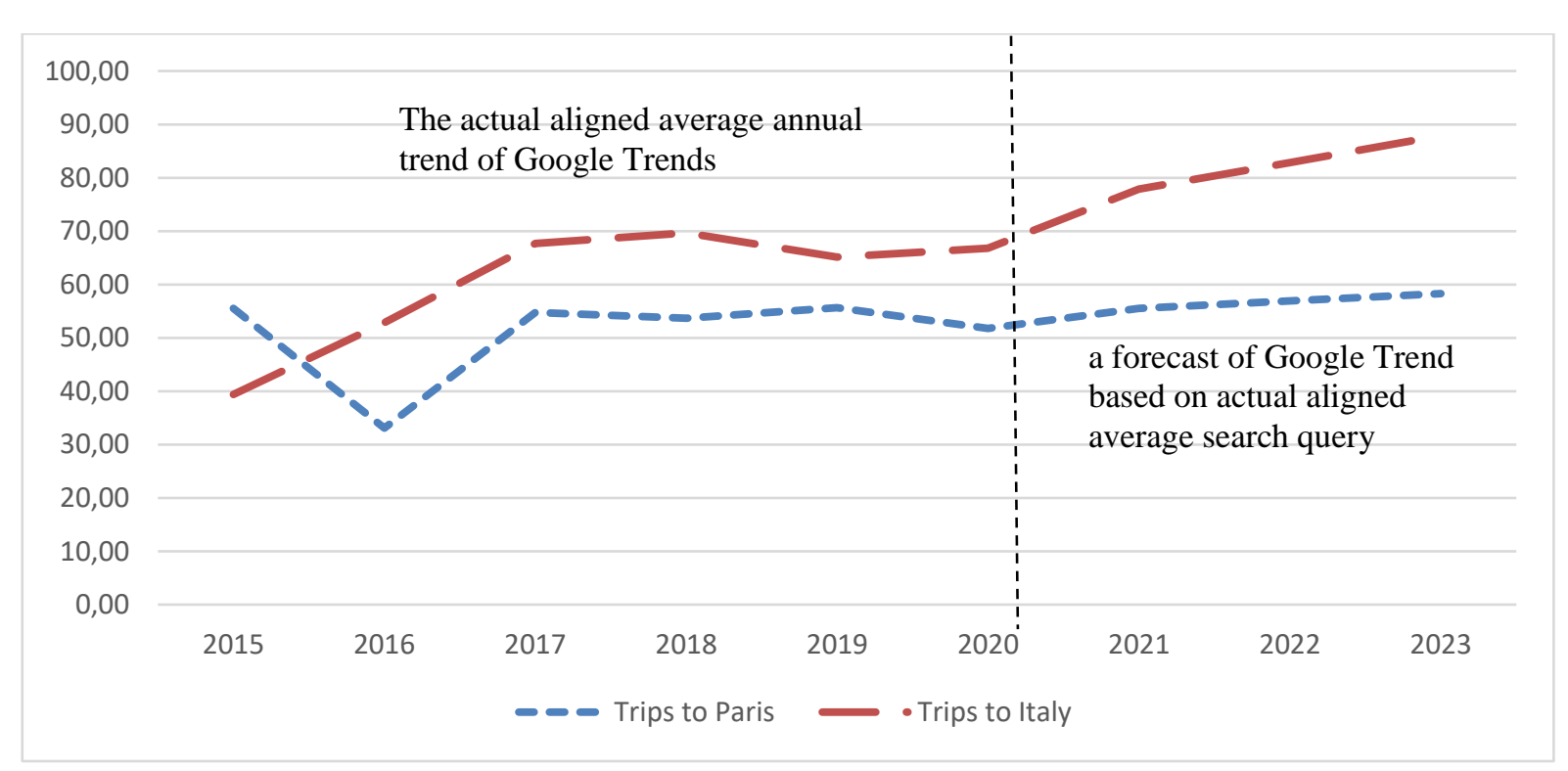

Graph 4. Forecast of search popularity on the basis of smoothing of average between Russianlanguage and English-language queries for tourist services

Since seasonality can be traced in "Tours to Italy" search frequency and the seasonal component can be distinguished, it is advisable to use Holt-Winters' three-parameter model to predict the effect of pent-up demand, which takes into account the smoothed exponential series, trend and also the seasonality of the indicator.

In turn, the dynamics of queries for "Trips to Paris" does not contain seasonal fluctuations, moreover, as mentioned above, the potential demand for tours to the capital of France is not as seasonal as it depends on external factors, usually political, then to forecast the pent-up demand and popularity of this destination among tourists it is advisable to use the Holt model, which can be used to predict the trend of dynamic series in which no seasonal component is detected.

This query situation shows that pent-up demand effect and the booking of tours in these areas is real after quarantine and the announcement of the end of the pandemic and the opening of borders for mass tourism.

In fact, the forecast indicates that pent-up demand can accumulate, which can, as a result, lead to a "boom" in demand and a conditional shortage in the tourist services market. In fact, a shortage in the tourist services market is unlikely, but possible in the travel package segment, as the travel package includes hotel and transport services, and hotel and airplane space are limited by their physical capacity.

\section{Conclusion}

Summarizing the study, it should be noted that the market for tourist services is extremely sensitive to various changes in the external environment and at the same time has significant features associated with the possibility of pent-up demand from consumers. pent-up demand can be estimated and forecasted. To a large extent, pent-up demand in the tourist services market is influenced by uncertainty factors. In this case, potential consumers begin to defer when the changes are significant. At the same time, society is looking for ways to optimize its accumulation, including through the preliminary realization of demand, that is, the acquisition of services to their actual need, which may be associated with a certain boom in early bookings for future seasons, as evidenced by English-language and Russian-language leisure requests received using Google Trends. 
Both optimistic and pessimistic scenarios of the tourist season launch during 2020 already allow to state the formation of pent-up demand effect on major tourist destinations. Significant role in this process plays the so-called "virtual travel", which were implemented with the help of modern information technologies by a number of tourist destinations and excursion sites. Thus, pent-up demand generation is already taking place in a "try before you buy" format and will become real demand as soon as restrictions on international travel will be lifted.

At the same time, it is advisable to consider trends indicating some changes in consumer expectations regarding travel arrangements. Thus, today we can talk about the trend of individualization of future travel, the desire to visit less popular tourist areas without unnecessary crowds and tourists, giving preference to boutique hotels or hotels with traditionally high level of service, where the consumer will be assured that all necessary safety standards are met, etc. In the fight for tourists will win those countries that competently and on time will orient and make a qualitative promotion of their tourist offers. The Second Breath will be given to the MICE industry by hosting conferences and workshops postponed to a later postquarantine period.

While tourism is in the stage of waiting, many hoteliers use this time to be ready for a new flow of guests: develop mobile applications, remind about themselves with useful content in the form of recipes from chefs, virtual tours, interesting facts about destinations, and airlines announce promotions that motivate tourists to plan travel now. That is why there is a tendency to claim that pent-up demand is real, and mostly applied to travel to popular tourist destinations.

So, the conducted correlation analysis and the constructed correlation matrix showed the existence of a close relationship between the popularity of English-language and Russianlanguage search queries and the indicators of tourist arrivals, and the constructed forecast confirmed the hypothesis that pent-up demand could accumulate and the market for tourist services expects a considerable boom, when the worldwide quarantine ends, with mathematical modeling of which the prospects for further research may be related.

\section{References}

Alekseev, N.E., \& Ilchenko, S.M. (2013). Demand trend as a factor of economic development. Omsk Scientific Herald, 5, 56-59.

Antokhonova, I.V. (2005). Consumer demand in a transition economy: a statistical research methodology. Publishing House of the BSC SB RAS.

Brown, G. R. (2004). Smoothing, Forecasting and Prediction of Discrete Time Series. Dover Phoenix Editions.

Carroll, C.D. (1997). Buffer-Stock Saving and the Life Cycle. Permanent Income Hypothesis, 12(1), 1-55.

COVID-19: UNWTO Calls on tourism to be part of recovery plans (2020, March 19). Retrieved from https://unwto.org/news/covid-19-unwto-calls-on-tourism-to-be-part-of-recoveryplans

Deaton, A. (1991). Saving and Liquidity Constraints. Econometrica, 59 (5), 1221-1248.

Drozdova, N.V., \& Perelomova, I.G. (2010). Economic-Mathematical Modeling. Yaroslavl State University.

Feoktistova, N.A. (2009). Development trends in the local (local) product market. Economics of Education, 2(3), 292-295.

Friedman, M., \& Savage L.J. (1948) Utility Analysis of Choices Involving Risk. Journal of Political Economy, 56(4), 279-304. 
Gaoa, Y., Rasoulib, S., Timmermansb, H., \& Wanga, Y. (2014). Reasons for not buying a car: a probit-selection multinomial logit choice model. Procedia Environmental Sciences, 22, $414-422$.

Guevara, G. (2020, March 1). El coronavirus costará al menos 20.000 millones de euros al turismo mundial. Retrieved from https://www.elmundo.es/economia/ macroeconomia/2020/02/27/5e 56c3fe21efa02a5d8b4714.html

Holt, C.C. (1957). Forecasting trends and seasonals by exponentially weighted moving averages. O.N.R. Memorandum, Carnegie Inst. of Technology.

Katona, G. (1951). Psychological A Bnalisys of Economic Behaviour. McGrow-Hill.

Novosyolov, A.S., \& Novosyolov, A.S. (2002). Theory of Region markets. Phoenix.

Oleynik, N.S. (2013). Marketing: Textbook. Nizhny Novgorod.

Roudposhti, V.M., Nilashi, M., Mardani, A., Streimikiene, D., Samad, S., \& Ibrahim, O. (2018). A new model for customer purchase intention in ecommerce recommendation agents. Journal of International Studies, 11(4), 237-253. doi:10.14254/2071-8330.2018/11-4/17

Solomatina, A.N. (2000). Economy and organization of commercial enterprises. INFRA-M.

Streimikiene, D., \& Bilan, Y. (2015). Review of rural tourism development theories. Transformations in Business and Economics, 14(2), 21-34.

Theil, H., \& Wage S. (1964). Some observations on adaptive forecasting. Management Science, 10(2), 198-206.

Tourism and Coronavirus disease (COVID-19) (2020, March 20). Retrieved from https://unwto.org/tourism-covid-19-coronavirus

Tounta, P. (2020, March 5). Pandemic 2020: The impact on tourism and the shadowy points. Retrieved from https://www.traveldailynews.com/post/pandemic-2020-the-impact-ontourism-and-the-shadowy-points

Tversky, A., \& Kahneman, D. (1974). Judgment under Uncertainty: Heuristics and Biases. Science, 185, 1124-1131.

Vaitkevičius, S., Mažeikienė, E., Bilan, S., Navickas, V., \& Savanevičienè, A. (2019). Economic demand formation motives in online-shopping. Inžinerine ekonomika, 12, 631640.

Wahlund, R., \& Gunnarsson, J. (1996). Mental Discounting and Financial Strategies. J. Of Economic Psychol, 17, 709-730.

Winters, P. R. (1960). Forecasting sales by exponentially weighted moving averages. Management Science, 6(3), 324-342.

Zadoya, A.A. (2014). Aggregate demand as a factor and result of economic growth. Scientific works DonNTU, 1, 252-261. 